\title{
PERAN KONSELING KELUARGA DALAM MENGHADAPI GENDER DENGAN SEGALA PERMASALAHANNYA
}

\author{
Maryatul Kibtyah \\ IAIN Walisongo Semarang \\ email: mariyaqibtyah@yahoo.co.id
}

\begin{abstract}
Abstrak
Gender identik dengan jenis kelamin laki-laki dan perempuan. Permasalahan yang dibawa ke dalam proses konseling akan melibatkan seluruh anggota keluarga, karena pada dasarnya jenis kelamin laki-laki dan perempuan ini akan selalu hadir dalam sebuah keluarga manakala mereka sudah diikat oleh tali perkawinan yang syah. Oleh karena itu membicarakan gender secara otomatis akan berbicara juga masalah keluarga. Kompleksnya permasalahan yang diakibatkan oleh gender dalam sebuah keluarga, misalnya perbedaan pendapat tentang pentingnya pendidikan dalam keluarga, karir suami/istri, kepengurusan anak, kenakalan anak, hingga kekerasan dalam rumah tangga (KDRT) yang dialami istri/perempuan dan anak-anak, semua ini harus diselesaikan secara kekeluargaan dengan bantuan konselor yang memahami gender dengan segala permasalahan yang ditimbulkannya.
\end{abstract}

Kata kunci: konseling keluarga, konselor, gender

\section{A. Pendahuluan}

Berbicara tentang gender, pada dasarnya adalah membicarakan masalah kehidupan secara luas, karena permasalahan yang diakibatkan oleh kata gender itu sendiri juga kompleks. Mulai dari KDRT, kekerasan terhadap anak dan perempuan, pengasuhan anak, wanita karir, hubungan suami istri dan masih banyak lagi. Dalam masyarakat kita khususnya jawa, yang memandang bahwa wanita adalah konco wingking, suwargo nunut neroko katut masih berlaku kental dan yang menjadi pelaku penderita/korbannya adalah wanita. Pandangan seperti ini tidak bisa lepas dari sosial, budaya, ekonomi 
dan pendidikan seseorang/masyarakat dimana individu itu tinggal dan hidup, sehingga sangat mempengaruhi pandangannya terhadap gender. Seseorang yang hidup dan dibesarkan dalam lingkungan yang demokratis dan memandang bahwa antara pria dan wanita mempunyai persamaan hak dan kewajiban, maka untuk kehidupan selanjutnya dia akan berpandangan dan berpegang pemahaman yang seperti itu. Sebaliknya jika seseorang yang sejak awal dibesarkan dan dididik dalam lingkungan yang membedabedakan jenis kelamin, maka untuk ke depannya dia juga akan tetap berpegang pada perbedaan itu.

Penulis di sini akan mencoba mengurai lebih lanjut tentang peranan gender dalam proses konseling keluarga terhadap mereka yang terlibat di dalamnya, yaitu klien dan konselor. Di mana dalam proses konseling akan selalu ditemui berbagai macam ragam klien dengan segala persoalannya. Dengan demikian seorang konselor dituntut untuk memahami setiap persoalan yang dibawa klien dalam proses konseling, termasuk di sini adalah yang berkaitan dengan gender.

\section{B. Pengertian Konseling}

Begitu banyaknya definisi konseling yang disampaikan oleh para ahli, antara lain Shertzer \& Stone ${ }^{1}$ yang mengemukakan bahwa konseling adalah upaya membantu individu melalui proses interaksi yang bersifat pribadi antara konselor dan konseli, agar konseli mampu memahami diri dan lingkungannya, mampu membuat keputusan dan menentukan tujuan berdasarkan nilai yang diyakininya, sehingga konseli merasa bahagia dan efektif perilakunya.. Sedangkan menurut Burk \& Stefflre dalam Mc Leod, ${ }^{2}$ konseling mengindikasikan hubungan profesional antara konselor terlatih dengan klien. Hubungan ini biasanya bersifat individu ke individu, walaupun terkadang melibatkan lebih dari satu orang. Konseling didesain untuk menolong klien, untuk memahami dan menjelaskan pandangan mereka hlm. 19.

${ }^{1}$ Shertzer Stone, Fundamentals of Counseling, (Boston: Hougton Mifflin Company, 1980),

${ }^{2}$ Leod. John Mc. Pengantar Konseling Teori dan Studi Kasus, (Jakarta: Kencana Prenada Media Group, 2010), hlm. 5. 
terhadap kehidupan dan untuk memahami mereka mencapai tujuan penentuan diri (self determination) mereka melalui pilihan yang telah diinformasikan dengan baik serta bermakna bagi mereka, dan melalui pemecahan masalah emosional.

Sedangkan menurut Ivey \& Downing, ${ }^{3}$ konseling adalah suatu proses hubungan yang lebih intensif dan terarah antara seorang ahli dengan individu (manusia normal) untuk mencapai maksud (tujuan) yang lebih efektif.

Dari ketiga definisi tersebut dapat penulis simpulkan, bahwa konseling adalah suatu proses hubungan antara individu/manusia normal dengan seorang ahli dan bertujuan mampu memahami diri dan lingkungannya, kemudian membuat keputusan yang bermakna dan efektif.

Tujuan konseling menurut $\mathrm{Mc} \mathrm{Leod}^{4}$ yang merangkum dari beberapa teori dan pendekatan yang ada dalam konseling (psikodinamika, behaviorisme dan humanisme) adalah sebagai berikut; pemahaman terhadap akar dan perkembangan emosional mengarah kepada peningkatan kapasitas dan lebih memilih kontrol rasional daripada perasaan dan tindakan; berhubungan dengan orang lain; kesadaran diri; penerimaan diri; aktualisasi diri/individuasi; pencerahan; pemecahan masalah; pendidikan psikologi; memiliki keterampilan sosial; perubahan kognitif; perubahan tingkah laku; perubahan sistem; penguatan; restitusi (membantu klien membuat perubahan kecil terhadap perilaku yang merusak); reproduksi dan aksi sosial.

\section{Pengertian Keluarga}

Keluarga merupakan masyarakat terkecil yang sangat penting dalam membentuk karakter dan kepribadian bagi para anggota keluarganya. Perkembangan kepribadian seseorang merupakan wujud nyata peran serta anggota dalam keluarga. Keluarga merupakan hubungan atau interaksi

\footnotetext{
${ }^{3}$ Ivey Allen E \& Downing Lynn Simek. Counseling and Psychotherapy, Skill Theories and Practice, (Englewood Cliffs. N.J.: Prentice-Hall. Inc., 1980), hlm. 13.

${ }^{4}$ Ibid., hlm. 13.
} 
antara dua orang atau lebih dan mempunyai ikatan darah, ikatan karena pernikahan, kekerabatan yang di dalamnya terdapat suatu sistem yang saling mengikat satu sama lain, seperti adanya aturan-aturan, perbedaaan budaya, dan perbedaan peran setiap anggota. ${ }^{5}$

Menurut Pujosuwarno, keluarga adalah suatu ikatan persekutuan hidup atas dasar perkawinan antara orang dewasa yang berlainan jenis yang hidup bersama antara seorang laki-laki atau seorang perempuan yang sudah sendirian dengan atau tanpa anak-anak baik anaknya sendiri atau adopsi dan tinggal dalam sebuah rumah tangga. ${ }^{6}$

Keluarga adalah komunitas terkecil dalam masyarakat yang terdiri dari manusia yang tumbuh dan berkembang sejak dimulainya kehidupan, sesuai dengan tabiat dan naluri manusia, yaitu memandang sesuatu dengan matanya, menyikapi sesuatu dengan jalan hukum, kecenderungan memilih arah yang baik, serta mengupayakannya dengan segala yang dimilikinya. ${ }^{7}$

Dari ketiga definisi tersebut di atas, dapat penulis simpulkan, keluarga adalah unit terkecil dari suatu masyarakat yang terdiri dari seorang ayah, ibu dan beberapa orang anak yang mempunyai pertalian darah dan diikat dengan pernikahan yang sah.

\section{Konseling Keluarga}

Permasalahan yang sering muncul dalam kehidupan berkeluarga adalah, masalah ekonomi yang belum mapan; perbedaan watak/temperamen dan perbedaan kepribadian yang terlalu tajam antara suami istri; ketidakpuasan dalam hubungan seksual; kejenuhan rutinitas; hubungan antar keluarga yang kurang baik; adanya orang ketiga di antara suami/ istri;masalah harta dan warisan; menurunnya perhatian dari kedua belah pihak suami/istri; dominasi orang tua/mertua; kesalahpahaman antara

${ }^{5}$ Fatchiyah E. Kertamuda, Konseling Pernikahan untuk Keluarga Indonesia, (Jakarta: Salemba Humanika, 2009), hlm. 47.

6 Sayekti Pujosuwarno, Bimbingan dan Konseling Keluarga, (Yogyakarta: Menara Mas Offset, 1994), hlm. 11.

${ }^{7}$ Abd Hamid Kisyik, Bimbingan Islam untuk Mencapai Keluarga Sakinah, (Bandung: alBayan, 1995), hlm. 214. 
kedua belah pihak; poligami dan perceraian. Dari berbagai problematika itulah sehingga perlu adanya konseling keluarga.

Menurut Willis, Konseling keluarga adalah upaya bantuan yang diberikan kepada individu anggota keluarga melalui sistem keluarga (pembenahan sistem komunikasi keluarga) agar potensinya berkembang seoptimal mungkin dan masalahnya dapat diatasi atas dasar kemauan membantu dari semua anggota keluarga berdasarkan kecintaan dan kerelaan terhadap keluarga. Penanganan terhadap keluarga sebagai suatu sistem bertujuan untuk membantu anggota keluarga mengembangkan potensinya agar menjadi manusia yang berguna bagi keluarga dan bangsanya. Di samping itu juga membantu anggota keluarga yang mengalami gangguan emosi melalui sistem keluarga, yaitu setiap anggota keluarga memberikan kontribusi positif dan pemahaman yang mendalam akan hakekat gangguan tersebut. ${ }^{8}$ Dengan kata lain keluargalah yang berjasa untuk membantu perkembangan anggotanya dan menyembuhkan anggota yang terganggu. Lebih lanjut Willis mengatakan, di Indonesia konseling keluarga baru mendapat pengertian dari masyarakat terutama sejak pesatnya perkembangan kota dan industrialisasi yang cenderung dapat menimbulkan stres keluarga antara lain disebabkan menggebunya anggota keluarga memenuhi kebutuhan ekonomi, sehingga mereka jarang berkumpul di rumah dan terjadi pergeseran nilai dengan begitu cepat, sementara orang tua belum siap menerima dan masih berpegang dengan nilai-nilai lama.. Meski demikian, kendala budaya masih amat terasa pada pelaksanaan konseling keluarga. Orang Indonesia masih malu mengungkapkan masalah keluarganya di depan orang lain. Melihat kondisi seperti ini, bagi konselor memang agak sulit untuk menangani keluarga sebagai suatu sistem (ayah, ibu, anak dan anggota keluarga lainnya ) hal ini dikarenakan sebagai berikut:

Pertama, Keluarga (orang tua) merasa bahwa urusan anak (perilakunya) adalah urusan orang tua, dan orang tua berhak atas anaknya karena yang membiayai hidupnya. Kedua, terasa gengsi keluarga akan turun, kalau sampai konselor menangani masalah keluarga. Ketiga, kesukaran dalam

${ }^{8}$ Sofyan Willis, Konseling Keluarga, (Bandung: Alfabeta, 2009), hlm. 83. 
teknik konseling yang sesuai dengan kasus keluarga; keempat, hambatan dalam pribadi konselor sendiri, terutama konselor pemula.

Perez menyimpulkan hambatan itu sebagai berikut; ketakstabilan emosional; konselor memiliki sistem nilai tertentu yang digunakannya untuk menilai klien; konselor masih belum begitu menguasai teori dan teknik yang memadai. Di samping itu hambatan juga muncul dari pihak keluarga sendiri yaitu tidak mempunyai motivasi untuk berpartisipasi dalam konseling keluarga. ${ }^{9}$

Menghadapi hal-hal seperti ini, maka seorang konselor keluarga harus memiliki wawasan filosofis-teoritis manusia dan keluarga serta memiliki pengetahuan dasar konseling dan psikologi; berkepribadian dan memiliki keterampilan sebagai seorang konselor. Dalam menghadapi masalah keluarga sebaiknya konselor berada satu tingkat di atas klien dalam hal pengalaman berkeluarga dan pengalaman konseling, usianya berada di atas klien, karena dengan demikian, seorang klien akan menjadi lebih yakin mengadakan konseling dengan orang yang benar-benar mampu memahami keadaan kliennya karena sudah mengalaminya sendiri.

\section{E. Pengertian Gender}

Menurut Umar, gender adalah suatu konsep yang digunakan untuk mengidentifikasi perbedaan antara laki-laki dan perempuan dilihat dari segi sosial budaya, psikologis, non biologis. Sedangkan seks untuk mengidentifikasi perbedaan laki-laki dan perempuan dari sisi anatomi biologi. ${ }^{10}$ Sedangkan menurut Fakih, gender adalah suatu sifat yang melekat pada kaum laki-laki maupun perempuan yang dikonstruksi secara sosial maupun kultural. Misal: bahwa perempuan itu dikenal lemah lembut, cantik, emosional, keibuan, sementara laki-laki dianggap kuat, rasional, jantan. perkasa. Ciri dari sifat itu merupakan sifat-sifat yang dapat dipertukarkan, artinya ada laki-laki yang emosional, lemah lembut, keibuan, sementara ada juga perempuan yang

\footnotetext{
${ }_{9}^{9}$ Sofyan Willis, Konseling Keluarga, hlm. 86

${ }^{10}$ Nasaruddin Umar, Argumen Kesetaraan Gender Perspektif al-Qur'an, (Jakarta. Paramadina, 1999), hlm. 35.
} 
kuat, rasional, perkasa. Perubahan ciri dari sifat-sifat tersebut dapat terjadi dari waktu ke waktu dan dari tempat ke tempat yang lain. ${ }^{11}$

Beberapa masalah yang bisa muncul karena anggapan yang berbeda tentang gender, yaitu ketidakadilan, marginalisasi perempuan, subordinasi terhadap perempuan yang menganggap bahwa perempuan itu irasional dan emosional, sehingga dianggap mtidak mampu memimpin dan mendapatkan tempat yang tidak penting; sterotipe; segala bentuk kekerasan baik fisik maupun psikhis., dan beban kerja dalam rumah tangga porsinya lebih besar daripada laki-laki. Kiranya tidak berlebihan kalau dikatakan bahwa faktor tersebutlah yang memunculkan adanya gerakan feminisme.

\section{F. Teori-teori dalam Konseling}

Secara garis besar, teori-teori dalam konseling terbagi dalam tiga teori besar (grand theory), yaitu psikodinamika; behaviorisme; dan humanisme.

\section{Pendekatan Psikodinamik}

Teori ini merepresentasikan tradisi utama dalam konseling dan psikoterapi kontemporer. Konseling psikodinamik memberikan perhatian besar terhadap kemampuan konselor untuk menggunakan apa yang terjadi dalam hubungan antara klien dan konselor yang bersifat segera serta terbuka, untuk mengeksplorasi tipe perasaan dan dilema hubungan yang mengakibatkan kesulitan bagi klien dalam kehidupannya sehari-hari.

Tujuan dari konseling ini adalah untuk membantu klien mencapai kesadaran dan pemahaman terhadap alasan di balik masalahnya, kemudian menerjemahkan kesadaran ini ke dalam kemampuan yang matang dalam menghadapi berbagai masalah di masa mendatang. Agar proses ini dapat berjalan, konselor disyaratkan mampu menawarkan kepada klien lingkungan yang cukup aman dan konsisten agar klien bisa mengekspresikan fantasi dan dorongan yang menyakitkan atau memalukan secara aman. ${ }^{12}$ Tokoh

\footnotetext{
${ }^{11}$ Mansour Faqih, Analisis Gender dan Transformasi Sosial, (Yogyakarta: Pustaka Pelajar. 1999), hlm. 8 .

${ }^{12}$ Mansour Faqih, Analisis Gender.., hlm. 89.
} 
dari teori ini adalah Sigmund Freud, yang metode pengobatannya disebut dengan psikoanalisis. Ketidaksadaran menurut Freud adalah bagiann dari kehidupan mental seseorang yang berada di luar kesadaran langsung Dalam pandangannya Freud membagi pikiran manusia ke dalam tiga wilayah, yaitu: $i d$, ego dan superego. Id, merupakan wadah insting kepribadian, motif, keinginan yang harus dipenuhi tanpa menghiraukan waktu dan lingkungan yang penting kenikmatan tercapai; Ego, berfungsi sebagai mediator antara superego dan id, merupakan bagian rasional yang membuat keputusan dan berhubungan denga dunia luar; Superego, merupakan moral, yang membolehkan atau tidak melakukan sesuatu. ${ }^{13}$ Antara ketiganya, id, ego dan superego sering kali terjadi ketidak sesuaian dan seringkali pula menimbulkan kontroversi dalam kepribadian seseorang, untuk itu maka muncul mekanisme pertahanan diri berupa: a) Represi, dimotivasi sikap lupa; b). Deniel (penolakan ); c) Proyeksi diatributkan oleh hasrat /pikiran seseorang yang tidak dapat diterima; d) Displacement (pengarahan ulang dorongan): menghubungkan dorongan ( biasanya dorongan yang agresif) kepada target yang berbeda; e) Reaction formation (menilai pihak yang berlawanan): mempertahankan diri dari dorongan yang tidak dapat diterima dengan mengubah mereka menjadi lawan; f) Sublimasi, menemukan pengganti yang dapat diterima: mentranformasikan dorongan ke dalam bentuk perilaku yang lebih dapat diterima secara sosial; g) Regresi (penurunan perkembangan ): merespon perasaan internal yang dipicu oleh ancaman eksternal dengan mengulang perilaku kekanak-kanakan dari tahap perkembangan sebelumnya. ${ }^{14}$

\section{Pendekatan Behaviorisme}

Pendekatan ini bersumber dari psikologi behavioral (perilaku) dan memiliki tiga karakteristik, yaitu: pemecahan masalah (problem solving), pendekatan perubahan terfokus (change focussed approach) untuk menghadapi hlm. 5 .

${ }^{13}$ John Mc Leod, Pengantar Konseling, Teori, dan Studi Kasus, (Jakarta: Kencana, 2010),

${ }^{14}$ Ivey Allen E \& Downing Lynn Semek, Counseling and Psychoterapy, Skill Theories and Practice, (Englewood Cliffs, N.J: Practice Hall, 1980), hlm. 13. 
klien; penghormatan terhadap nilai ilmiah; dan memiliki perhatian yang lebih terhadap proses kognitif-alat untuk mengontrol dan memonitor tingkah laku mereka. Tokohnya: Pavlov, Skinner, Seligmen. ${ }^{15}$ Jika konselor behavioral membantu klien, adalah terjadinya perubahan yang relevan pada perilaku klien. Beberapa teknik dasar yang biasa digunakan dalam konseling behavioral adalah sebagai berikut: a) Latihan relaxasi, ada dua macam relaksasi, yaitu penekanan relaksasi kontras dan relaksasi langsung; b) Modelling; c) Reinforcement/penguatan positif; d) Charting, yaitu membuat suatu ukuran jarak dengan perubahan perilaku oleh klien sebelum, selama dan setelah terapi. Tehnik ini bisa digunakan untuk latihan komunikasi keluarga, menjaga kebersihan ruangan, program berhenti dari merokok. ${ }^{16}$

\section{Pendekatan Humanisme}

Teori ini muncul karena adanya ketidakpuasan dari dua teori sebelumnya, yaitu psikodinamik dan behaviorisme. Dalam konseling dan psikoterapi, pendekatam humanistik yang paling luas digunakan adalah pendekatan person-centered dan Gestalt. Komposisi yang biasa terdapat dalam semua pendekatan humanistik adalah penekanan terhadap experiential processes. Perhatian utama Rogers dan teoritikus person centered lainnya adalah untuk mengembangkan sebuah pendekatan yang efektif, bukan terlibat dalam spekulasi yang teoritik. Salah satu karakteristik unik dari citra person dari person centered adalah usahanya untuk mendeskripsikan seseorang yang berfungsi penuh (fully functioning). Tiga komposisi hubungan terapeutik yang memiliki kecenderungan untuk menarik perhatian paling besar dalam pendidikan maupun riset person centerd adalah kualitas penerimaan konselor, empati dan keaslian. ${ }^{17}$

\section{G. Aplikasi Teori-teori dalam Konseling Keluarga}

Aplikasi teori-teori konseling dalam prakrik konseling keluarga merupakan suatu keharusan, dengan menggunakan satu teori dalam me-

\footnotetext{
${ }^{15}$ John Mc Leod, Pengantar Konseling..., hlm. 95.

${ }^{16}$ John Mc Leod, Pengantar Konseling..., hlm. 95.

${ }^{17}$ John Mc Leod, Pengantar Konseling..., hlm. 246.
} 
nangani masalah keluarga dirasa sangat sulit, maka banyak konselor keluarga menggunakan beberapa macam teori yang dianggap sesuai dan cocok untuk permasalahan yang diajukan oleh klien. Dalam bagian tulisan sebelumnya sudah penulis sajikan tentang beberapa macam teori yang ada dalam konseling dan sering digunakan, maka dalam bagian ini penulis ingin mencoba menampilkan aplikasi dari beberapa teori tersebut ke dalam konseling keluarga.

Konsep konseling psikodinamika mengajarkan konselor untuk memahami tentang ketakberfungsian pola-pola keluarga yang telah menyebabkan isu-isu pribadi yang tak terpecahkan di antara ayah, ibu dan anak gadisnya. Di dalam konseling keluarga, situasi yang tak menentu itu merupakan pola masa lalu yang terungkap di masa sekarang di dalam keluarga. Tantangan terbesar dari konselor adalah untuk membantu anggota keluarga agar menyadari keadaannya dan mengambil tanggung jawab dalam menanggulangi proyeksi dan transferensinya dan memahami bahwa masalah keluarga masih saja berlarut-larut seandainya mereka masih terus-menerus berorientasi secara tak sadar kepada kehidupan masa lalunya. Pendekatan ini menunjukkan bahwa suatu kekuatan yang ditempuh untuk memecahkan masalah keluarga sebagai suatu sistem dengan tujuan mencapai perubahan struktur kepribadian orang tua. Jika mereka sadar tentang kebutuhan dan motivasi-motivasinya yang tak disadari itu, sebagai yang ia alami di masa lalu dalam "luka" psikhis, dan jika mereka sadar akan hubungan yang dinamik antara pengalaman-pengalamannya sebagai anak-anak serta perannya sekarang sebagai orang tua, maka kemungkinan baru terbuka bagi orang tua itu untuk mencapai perubahan bagi pribadinya dan situasi keluarganya. ${ }^{18}$

Hal ini seperti yang dikatakan Kertamuda, psikodinamika merupakan bagian dari pengalaman masa kanak-kanak dalam hubungannya dengan ibu yang dapat menjadi hal penting dalam pembentukan kepribadiannya di masa dewasa. Dalam kehidupan keluarga konflik dan kehidupan anggota keluarga menjadi perhatian. ${ }^{19}$

${ }^{18}$ John Mc Leod, Pengantar Konseling..., hlm. 189.
${ }^{19}$ John Mc Leod, Pengantar Konseling..., hlm. 189. 
Psikodinamika memberikan kontribusi terhadap hubungan antara orang tua dan anak serta ketidakberfungsian keluarga. Menurut Gladding dalam Kertamuda, ada tiga cara agar dapat mengatasi masalah dalam keluarga, yaitu: mengembangkan dengan kuat koalisi orangtua, mengartikan dan menjaga ikatan dari generasi ke generasi, serta memberikan model nyang psitif terhadap peran dalam setiap hubungan. Peran konselor dalam konseling keluarga adalah membantu anggota keluarga memperoleh pemahaman dan pemecahan konflik, mengurangi ketidakjelasan terhadap suatu masalah, merekonstruksi hubungan yang terdapat dalam keluarga dan mendukung pertumbuhan setiap individu dan keluarga. Lebih lanjut dijelaskan, bahwa konselor dalam pendekatan ini dapat membantu keluarga dengan melakukan rekonstruksi hubungan dalam keluarga tersebut. Cara ini dilakukan karena selama ini keluarga mereka tidak memperoleh pemahaman terhadap masalah yang timbul, sehingga hubungan dalam keluarga terganggu. Konselor membantu dan mendukung agar setiap anggota keluarga dapat menyadari diri mereka masing-masing, mulai dari kesadaran akan perilaku, sikap, sifat dan cara menyalurkan emosi. Hal ini penting karena melalui kesadaran terhadap diri sendiri, maka akan dapat membantu interaksinya dengan prang lain. Melalui interaksi yang baik, maka dapat terjalin hubungan yang baik antar anggota keluarga. Apabila ini dapat dilakukan, maka setiap mindividu dalam keluarga dapat tumbuh dengan baik dan dapat meningkatkan kualitas hubungan keluarga.

Teori Psikodinamika menyarankan, bahwa untuk memahami klien, konselor perlu mengerti mind sets dan dinamika klinis dari klien. Konselor dapat melakukan proses identifikasi permasalahan yang dihadapi anggota keluarga lebih awal, sehingga dapat menyatukan keluarga melalui pengalaman. Konselor juga dapat lebih sensitif dan bekerja secara efektif agar anggota keluarga yang terlibat dapat memiliki kesiapan dan menyesuaikan dengan situasi yang akan dihadapinya. ${ }^{20}$

Konselor Behavioral telah memperluas prinsip-prinsip teori belajar sosial terhadap konseling keluarga. Mereka mengemukakan bahwa

${ }^{20}$ Kertamuda, Konseling Pernikahan ..., hlm. 142. 
prosedur-prosedur belajar yang telah digunakan untuk mengubah perilaku dapat diaplikasikan untuk mengubah perilaku yang bermasalah di dalam suatu keluarga. Liberman (1981) dalam Willis menjelaskan strategi behavioral yang khusus di dalam keluarga, Pertama kali sebagaimana anggota keluargha berinteraksi satu sama lain dapat diterjemahkan ke dalam behavioral dan belajar, dengan memfokuskannya pada akibat-akibat perilaku atau kemungkinan-kemungkinan reinforcement. Artinya, bahwa anggota keluarga belajar bagaimana memberikan kepada anggota lain pengenalan dan persetujuan perilaku-perilaku yang diinginkan dan bukan perilaku yang menyimpang. Karena itu proses perubahan kemungkinan perilaku-perilaku itu adalah prinsip dasar konseling behavioral dalam keluarga. Sedangkan yang menjadi ciri utama dari aplikasi behavioral terhadap konseling keluarga adalah: kreasi dari gabungan terapeutik yang positif; membuat analisa fungsional terhadap masalah-masalah dalam keluarga serta implementasi prinsip-prinsip behavioral yaitu reinforcemet dan modelling di dalam konteks interaksi dalam keluarga. ${ }^{21}$

Teori Humanisme menekankan, bahwa klien secara individual dalam keanggotaan kelompok akan mencapai kepercayaan diri, di mana dia mengatakan, bahwa anggota anggota keluarga dapat mempercayai dirinya. Hal ini bisa terjadi jika kondisi-kondisi utama ada yaitu: kejujuran, keaslian, memahami, menjaga, menerima, menghargai secara positif dan belajar aktif. Dalam pendekatan ini, konselor berfungsi sebagai fasilisator, tujuannya untuk memudahkan membuka dan mengarahkan jalur-jalur komunikasi apabila ternyata dalam kehidupan keluarga tersebut pola-pola komunikasi telah berantakan bahkan terputus sama sekali. Kondisi-kondisi inti dari hubungan terapeutik yang dikemukakan dalam teori ini, merupakan hal yang penting dalam konseling keluarga. Pendekatan ini diwakili oleh Rogers yang memiliki asumsi dasar, bahwa sikap konselor sangat menentukan terhadap keterbukaan anggota keluarga dalam setiap sesi. Konselor tidak melakukan pendekatan terhadap anggota keluarga sebagai seorang pakar yang akan menerangkan rencana treatment-nya, tetapi

\footnotetext{
${ }^{21}$ Sofyan Willis, Konseling Keluarga....
} 
berusaha untuk menggali sumber-sumber yang ada di dalam keluarga, yaitu bahwa anggota keluarga mempunyai potensi untuk berkembang. ${ }^{22}$

\section{H. Teori-teori dalam Gender}

Beberapa teori yang ada dalam gender menurut Umar, adalah sebagai berikut:

1. Teori Psikoanalisa/Identifikasi, oleh Sigmund Freud, karakteristiknya adalah bahwa perbedaan perbedaan gender ditentukan oleh faktor psikologis. Perkembangan relasi gender mengikuti perkembangan psikoseksual, terutama dalam masa phallic stage ketika seorang anak menghubungkan identitas ayah ibunya dengan alat kelamin yang dimilikinya. Pandangan ini terlalu seksis. karena menafikan faktor lain yang ikut berperan dalam pembentukan gender.

2. Teori Struktural Fungsionalisme, pendapatnya, bahwa sistem yang terintegrasi dari berbagai unsur menjadikan masyarakat stabil. Setiap unsur harus berfungsi menurut fungsinya. Laki-laki dan perempuan masing-masing menjalankan perannya yang berbeda.

3. Teori konflik, menekankan pebagian kelas. Sebagian diuntungkan dan sebagian dirugikan. Basis ekonomi yang tidak adil memicu terjadinya konflik dan perubahan sosial. Terjadinya sub ordinasi perempuan akibat pertumbuhan hak milik pribadi.

4. Teori Feminis, yang menganggap, bahwa kodrat perempuan tidak ditentukan faktor biologis, melainkan faktor budaya masyarakat. Sistem patriarki perlu ditinjau, karena merugikan perempuan. Kemitrasejajaran laki-laki dan perempuan diusulkan sebagai ideologi dalam tata dunia baru.

5. Teori Sosio-biologis, memandang, bahwa gabungan faktor biologis dan faktor sosial menyebabkan laki-laki lebih unggul dari pada perempuan. Fungsi reproduksi perempuan dianggap sebagai faktor penghambat untuk mengimbangi kekuatan dan peran laki-laki. ${ }^{23}$

${ }^{22}$ Sofyan Willis, Konseling ..., hlm. 128.

${ }^{23}$ Sofyan Willis, Konseling ..., hlm. 114. 
Sedangkan menurut Faqih, selain teori-teori tersebut dia menambahkan beberapa teori sebagai berikut:

1. Teori Evolusi; pada awal masa teori ini menurut Hegel berdasarkan pada asumsi tentang perubahan, yaitu: natural, direksional, imanen, kontinu, suatu keharusan, berjalan melalui sebab universal yang sama. Sedangkan menurut Comte perubahan selalu mulai dari fase teologis di mana masyarakat dik;uasai oleh pendeta dan diperintah oleh militer; Fase ke dua adalah adalah metafisis, di mana dosa berdasarkan pada pemikiran filosofis manusia; Fase ketiga adalah ilmiah atau positif, yaitu dengan memahami hukum alam dan eksperimentasiilmiah. Pokok pikiran dari teori ini adalah, masyarakat bergerak dari masyarakat miskin non industri, primitif, akan berevolusi ke masyarakat industri yang lebih kompleks dan berbudaya., yang menjadi sumber persoalan adalah tradisi.

2. Teori Modernisasi, menurut Huntington, proses modernisasi bersifat revolusioner, kompleks, sistematik, global, bertahap, hegemonisasi dan progresif. Teori ini banyak dianut oleh kalangan interdisiplin sosiologis, psikologi, ilmu politik, ekonomi, antropologi bahakan kalangan agama.

3. Teori Sumber Daya Manusia, dikembangkan oleh Theodore Shultz dengan tema yang dikenal sebagai investasi dalam sumber daya manusia

4. Teori Ketergantungan, teori ini berlawanan dengan teori evolusi dan modernisasi. Teori ini menekankan hubungan dalam masyarakat, misalnya masalah struktur sosial, kultur, ekonomi dan politik. Asumsi dari teori ini adalah, bahwa keterbelakangan dan dan pembangunan merupakan konsep yang saling berkaitan. ${ }^{24}$

Dari beberapa teori yang muncul, antara teori yang ada dalam konseling dan teori gender disebabkan oleh persoalan yang ada dan terjadi pada saat itu serta adanya ketidakpuasan/ketidaksetujuan dengan teori sebelumnya.

\footnotetext{
${ }^{24}$ Mansour Faqih, Analisis Gender.., hlm. 29.
} 


\section{Konseling dan Terapi Gender}

Dalam beberapa literatur konseling dan psikoterapi, keberadaan gender menduduki tempat tersendiri. Beberapa istilah yang digunakan adalah unisex, feminisme, maskulin, dan gemder itu sendiri. Isu gender sudah lama muncul, bangkitnya feminisme dan tumbuhnya gerakan laki-laki telah meningkatkan perdebatan tentang peran laki-laki dan perempuan. Isu ini akhirnya merembes ke terapi, misalnya dalam asumsi-asumsi terkait gender yang dibawa terapis dan klien ke dalam kehidupan pribadinya, maupun ke dalam terapi. ${ }^{25}$

Tujuan terapi untuk kedua jenis kelamin pada umumnya untuk membantu masing-masing klien menggunakan kekuatan dan potensinya, membuat pilihan yang tepat guna, memperbaiki keterampilan yang buruk dan mengembangkan konsep diri yang positif dan fleksibel. Di samping itu tujuan terapi yang berkaitan dengan peran gender sering kali bisa melibatkan kedua pasangan. ${ }^{26}$ Konseling feminis merupakan model terapi yang relatif baru. Khusus tentang teori dan praktik konseling terhadap feminis, ada beberapa pendekatan yang bisa digunakan, yaitu: pendekatan integrasionis, yaitu menciptakan integrasionisme feminis yang terinformasikan dengan baik, dengan segala kekuatan dan kelemahan yang diasosiasikan secara umum kepada pendekatan integratis dan feminis.; terapi feminis model Stone Center yang dikembangkan oleh Miller merupakan suatu usaha untuk memahami dimensi psikologis ketidaksamaan sosial dan kekuasaan yang dialami oleh wanita. Konsep inti dari model ini adalah relatedness (keterhubungan) dan self-in-relation (posisi diri dalam hubungan); Terapi feminis radikal, yang tertarik kepada lingkungan sosial dan material di mana wanita itu tinggal. ${ }^{27}$

Konseling feminis bermaksud memberdayakan orang dan mengembangkan rasa percaya diri yang lebih besar dan kontrol atas kehidupannya. Tujuan terapi untuk laki-laki dapat mencakup paling tidak tiga

\footnotetext{
${ }^{25}$ Mansour Faqih, Analisis Gender ..., hlm. 29.

${ }^{26}$ Mansour Faqih, Analisis Gender ..., hlm. 704.

${ }^{27}$ Mansour Faqih, Analisis Gender ..., hlm. 704.
} 
isu yang diidentifikasi dalam gender-role-conflict-scale, yaitu kebutuhan eksesif untuk sukses, kekuasaan dan persaingan,emosionalitas yang terbatas dan perilaku kasih sayang yang terbatas di antara kaum laki-laki. ${ }^{28}$

Munculnya gerakan yang mengatasnamakan gender, mempengaruhi pendekatan yang ada dalam konseling secara umum untuk ikut serta memecahkan persoalan tersebut. Banyak terapis laki-laki maupun perempuan untuk melaksanakan terapi dengan fokus yang lebih besar untuk menyembuhkan distress psikologis yang berasal dari sosialisasi peran gender yang restriktif dan seksisme.

Pendekatan psikodinamik oleh Jung lebih menekankan pentingnya feminitas dari pada Freud. Jung mengakui pentingnya arketip ibu, yang tampak pada banyak aspek. Di smping itu Jung menganggap manusia biseksual secara psikologis, bahwa laki-laki memiliki anima (personifikasi sifat feminin dalam ketiksadarannya) dan perempuan memiliki animus (personifikasi sifat maskulin dalam ketidaksadarannya). Psikologi Jungian menyediakan dasar untuk mengeksplorasi isu-isu peran gender dengan tingkat kesadaran yang bervariasi.

Pendekatan humanistik dapat digunakan dan diadaptasikan untuk menangani isu-isu peran gender. Klien dalam terapi person centerd dapat mengalami dan mengeksplorasi isu-isu yang berhubungan dengan sosialisasi peran gender sebelumnya dan isu-isu peran gender saat ini serta konflikkonflik dalam iklim emosional yang aman dan terpercaya Terapis gestalt dapat menggunakan intervensi-intervensi, seperti eksperimen kesadaran, penggunaan kursi kosong dan analisis mimpi untuk memfokuskan pada pembelajaran peran gender dan perilaku-perilaku yang memblokir kesenangan dan kehidupan sejati.. Di samping itu, dalam analisis transaksional, terapis dapat membantu klien untuk mengeksplorasi petunjuk skrip tentang perilaku-perilaku peran gender dan mencapai kebebasan memilih untuk membuang hal-hal yang bersifat merusak.

Pendekatan behavioristik juga memberikan fokus pada isu-isu peran gender. Misalnya dalam rasional emotif, keyakinan irrasional terkait gender

\footnotetext{
${ }^{28}$ John Mc Leod, Pengantar Konseling.., hlm. 244.
} 
dapat dideteksi, didispute (diperdebatkan) dan dibuang atau disajikan kembali menjadi lebih rasional. Dalam kognitif terapi, terapis dan klien dapat mengidentifikasi dan mempertanyakan realitas pikiran-pikiran otomatis terkait gender yang mengacaukan fakta dengan inferensi. Bilamana perlu, terapis dapat bekerja bersama klien untuk mengganti pikiran-pikiran otomatis sebelumnya yang seksis dan selfoppressing (menindas diri) dengan pikiran yang sadar dan realistis. ${ }^{29}$

\section{J. Peran Konseling Keluarga dalam Menghadapi Permasalahan Gender}

Dalam proses konseling seharusnya tidak terjadi bias gender dan tidak bias budaya, sehingga muncul konseling lintas budaya dan konseling multikultural. Hal ini selalu ditekankan pada semua orang yang tertarik dan berkecimpung di dunia konseling. Menghadapi permasalahan gender, harus juga memahami permasalahan dan pengalaman dari dua jenis kelamin yang terlibat di dalamnya. Bagi pihak perempuan, memiliki pengalaman dan isu-isu yang memunculkan adanya tuntutan agar mereka dihargai oleh lawan jenisnya. Munculnya gerakan perempuan juga menekankan pentingnya permpuan memahami dan menghargai pengalamannya sendiri. Salah satu cara melihat pengalaman perempuan adalah dalam kaitannya dengan interaksi sosial, politik dan personil. Selain itu adalah dengan tantanga-tantangan khas sepanjang hidup karena menjadi seorang perempuan. Misalnya ketegangan pra menstruasi, infertilitas dan keguguran, melahirkan, depresi pasca melahirkan, menjadi ibu, menopause, dan berumur lebih panjang dari pada suaminya. Masih ada cara lain untuk melihat pengalaman perempuan, yaitu dalam kaitannya dengan masalahmasalah yang menimpa perempuan dengan derajat yang beragam, misalnya kekerasan dalam rumah tangga, pelecehan seksual, penganiayaan seksual, tekanan tanpa belas kasihan untuk cantik, anoreksia, bulimia, perkosaan, aborsi, menjadi orang tua tunggal, sikap-sikap yang meng-

${ }^{29}$ Jones-Nelson, Richard, Theory and Practice of Counseling and Therapy Fourth edition (terj), (Yogyakarta: Pustaka Pelajar, ---), hlm. 706. 
hambat pemilihan karier, diskriminasi tempat kerja dan depresi serta kelelahan karena harus memikul bagian tanggung jawab pekerjaan/keluarga yang lebih besar. ${ }^{30}$

Dalam sebuah keluarga kedudukan laki-laki sebagai kepala keluarga dan pemimpin rumah tangga serta mempunyai kewajiban menafkahi seluruh anggota keluarga. Demikian pula adanya perempuan sebagai istri dan pendamping suami dan ibu bagi anak-anak memiliki tugas dan kewajiban mendidik dan membesarkan anak-anaknya serta mengurus kehidupan rumah tangganya. Kewajiban suami merupakan hak istri demikian sebaliknya kewajiban istri merupakan hak suami. Manakala masing-masing anggota keluarga melaksanakan hak dan kewajibannya dengan baik, kehidupan rumah tangga akan berjalan aman-aman saja dan tidak akan muncul gejala-gejala yang mengakibatkan permasalahan yang kompleks.

Namun yang namanya orang hidup tidak mungkin lepas dan terhindar dari yang namaya problem kehidupan, dari masalah anak-anak sampai pada masalah orang dewasa. Di sinilah diperlukan konselor yang benarbenar memahami gender dengan segala permasalahannya, termasuk pengalaman dalam berkeluarga. Beberapa keterampilan yang perlu dimiliki oleh seorang konselor dalam konseling keluarga terkait dengan pendekatan sistem keluarga menurut Willis adalah sebagai berikut:

1. Teknik-teknik yang berhubungan dengan pemahaman diri, meliputi teknik keterampilan mendengarkan; keterampilan memimpin; keterampilan merefleksi; ketrrampilan menyimpulkan; keterampilan mengkonfrontasi; keterampilan menafsirkan dan keterampilan menginformasikan.

2. Keterampilan untuk menyenangkan dan menangani krisis, meliputi: keterampilan mengadakan kontak; keterampilan menentramkan hati klien; keterampilan merelaksasi/ santai; keterampilan mengurangi/ meringankan krisis dengan mengubah lingkungan klien; keterampilan mengembangkan alternati- lain mengatasi krisis; keterampilan mereferal klien.

\footnotetext{
${ }^{30}$ John Mc Leod, Pengantar Konseling...., hlm. 709.
} 
3. Keterampilan untuk mengadakan tindakan positif dan perubahan perilaku klien. Keterampilan ini banyak diwarnai oleh aliran behavioral terapi, yang bertujuan agar setelah selasai konseling klien akan mengalami perubahan perilaku dan mampu melakukan tindakan positif. ${ }^{31}$

Pandangan terhadap gender dari masing-masing pihak antara suami dan istri akan menimbulkan masalah dalam sebuah keluarga. Hal ini harus dikomunikasikan sejak awal sebelum terjadinya ikatan perkawinan. Adanya komitmen ini akan mempengaruhi kehidupan keluarga selanjutnya. Oleh karena itu kesepahaman suami istri dan anggota keluarga lain terhadap gender harus dilakukan, baik oleh keluarga itu sendiri maupun oleh konselor.

\section{K. Simpulan}

Demikian yang bisa penulis sampaikan. Dari sini bisa disimpulkan kebanyakan pendekatan konseling dan terapi yang sudah ada tidak cukup melihat sosialisasi peran gender dan masalah-masalah serta isu-isu terapeutik yang timbul darinya. Terapi feminis adalah contoh utama dari upaya untuk memperbaiki kelalaian itu. Masih ada ruang yang cukup besar untuk melahirkan pendekatan-pendekatan dan terapi baru, maupun untuk memodifikasi pendekatan-pendekatan yang sudah ada yang bertujuan untuk mempromosikan kesetaraan di antara jenis kelamin.[]

\section{Daftar Pustaka}

Corey, Gerald, Theory and Practice of Counseling and Psychotherapy. 6 th Edition. Brooks/cole. Thomson Learning, 1990.

Faqih, Mansour, Analisis Gender dan Transformasi Sosial, Yogyakarta: Pustaka Pelajar, 1999.

Ivey Allen E \& Downing Lynn Simek. Counseling and Psychotherapy, Skill, theories and practice, Englewood Cliffs. N.J.: Prentice-Hall. Inc., 1980.

${ }^{31}$ Sofyan Willis, Konseling ..., hlm. 141-146. 
Jones-Nelson, Richard, Theory and Practice of Counseling and Therapy Fourth edition (terj), Yogyakarta: Pustaka Pelajar.

Kertamuda. Fatchiyah E. Konseling Pernikahan untuk Keluarga Indonesia, Jakarta: Salemba Humanika. 2009.

Kisyik, Abd Hamid, Bimbingan Islam untuk Mencapai Keluarga Sakinah, Bandung: al-Bayan, 1995.

Leod. John Mc. Pengantar Konseling Teori dan Studi Kasus. Jakarta: Kencana Prenada Media Group, 2010.

Pujosuwarno. Sayekti. Bimbingan dan Konseling Keluarga. Yogyakarta: Menara Mas Offset. 1994.

Shertzer Stone, Fundamentals of Counseling, Third Edition. Boston: Hougton Mifflin Company, 1980.

Umar, Nasaruddin. Argumen Kesetaraan Gender Perspektif al-Qur'an, Jakarta: Paramadina, 1999.

Willis, Sofyan, Konseling Keluarga, Bandung: Alfabeta, 2009. 